\title{
La acción diplomática de la Segunda República Española en México (1931-1939)
}

\author{
Mercedes Montero Caldera
}

\section{RESUMEN}

En mayo de 1931, los gobiernos de México y España acordaron elevar el rango de sus correspondientes legaciones a la

categoría de embajadas mostrando de este modo, su voluntad de establecer nuevos y

más intensos canales de entendimiento. Entre marzo y abril de 1939, a instancia de México, se produjo la cancelación oficial de relaciones diplomáticas.

Durante esos nueve años, ambos países compartieron un mismo objetivo, salvando las diferencias, como fue el llevar adelante un programa modernizador de sus estructuras políticas, económicas y sociales.

Dentro de ese contexto, este artículo trata de analizar la acción diplomática española en México durante ese periodo a través de la actuación de sus representantes alli acreditados. Dejando a un lado la retórica de los discursos oficiales y la utopía de los grandes proyectos, su objeto es la ejecución cotidiana

\section{ABSTRACT}

In May 1931, the Governments of Mexico and Spain reached the agreement of upgrading their respective diplomatic missions to the status of Embassies, thus showing their willingness to develop new and deeper links of mutual understanding. Between March and April 1939, the diplomatic relationship was cancelled by Mexico's initiative.

For those nine years, similar purposes, which were to pave the way for a modernization program of the political, economic and social structures, were shared by both nations.

Within this framework, this article is an attempt to analyse the diplomatic Spanish action in Mexico during that period throughout their representatives accredited there. Leaving aside the rhetoric of the official speeches and the utopia of the grand projects, the goal of the article is the day-to-day practice of that diplomacy, the attitudes and personal features of those 
de esa diplomacia, las actitudes

y talantes personales de aquellos, así como los fines concretos que, en ocasiones, el azar y las circunstancias impusieron a sus respectivas misiones.

Palabras clave: Segunda República. Guerra Civil. Diplomacia. España. México. diplomats, as well as the particular intentions imposed occasionally by coincidence and circumstances to each mission.
Key words: Second Republic. Civil war. Diplomacy. Spain. Mexico

\section{ABREVIATURAS}

A.H.D.M. Archivo Histórico Diplomático Mexicano.

AGA. AE. Archivo General de la Administración, Sección Asuntos Exteriores.

A.M.A.E. Archivo del Ministerio de Asuntos Exteriores.

B.O.M.E. Boletín Oficial del Ministerio de Estado.

C. Caja.

Exp. Expediente.

F.P.I. Fundación Pablo Iglesias.

Leg. Legajo.

P. Sección de Personal. Ministerio de Asuntos Exteriores.

R. Archivo Renovado. Ministerio de Asuntos Exteriores.

R.E. Archivo de Barcelona. Ministerio de Asuntos Exteriores.

\section{INTRODUCCIÓN}

Durante el periodo que transcurre desde 1931 hasta 1939 el contexto ideológico que constituyó el marco dentro del cual se desenvolvieron las relaciones diplomáticas hispano-mexicanas estuvo protagonizado por dos ejes con extremos opuestos surgidos en dos áreas geográficas distintas, Hispanoamérica, marco del enfrentamiento hispanoamericanismo/ panamericanismo, y Europa del comunismo/fascismo. La proyección de este último en aquel área, en especial a partir de 1936, más que sustituir, irá desplazando progresivamente al primero de ellos como circunstancia determinante de las relaciones entre ambos paises y de cada uno de 
ellos con Estados Unidos. Este país, si bien durante esta década no tenía el protagonismo internacional que adquirió en la siguiente, sin embargo su presencia en el área hispanoamericana jugó un papel determinante en las relaciones entre ambos países aunque a dos niveles diferentes: en relación a España las consecuencias derivadas de la misma a penas transcendió del ámbito de las mentalidades; respecto a México se plasmó en realidades concretas en especial en el ámbito de la economía.

La oposición dialéctica entre hispanoamericanismo/ panamericanismo, enfocado desde las ópticas conservadora/ progresista por los intelectuales españoles, constituyó en la década que comprende este trabajo un lugar común entre los políticos y diplomáticos españoles acreditados en México. Por su parte y en relación a este país, el enfrentamiento entre hispano-paramericanismo se inscribe acerca del debate de su propia identidad como nación concebido como una disyuntiva entre seguir siendo como ya era por herencia del pasado colonial o llegar a ser por imitación como su vecino del Norte.

En relación al segundo eje ideológico aludido, hay que decir, que a medida que transcurre la década de los treinta, la presencia en el contexto europeo, y en algunos países americanos del fascismo, tuvieron como consecuencia una variación profunda en los planteamientos del hispanoamericanismo conservador, introduciendo en él un componente nacionalista y religioso que le harían desaparecer dando lugar a una pseudo filosofía con fuertes componentes fascistas denominada la hispanidad, concebida como salvaguarda permanente frente al anticlericalismo y el comunismo.

Es en estas coordenadas donde desempeñaron su misión los cuatro embajadores españoles acreditados en México así como sus homólogos en nuestro país. Aunque la retórica de la documentación diplomática manejada parece acortar las distancias ideológicas, sin embargo no consigue ocultar las diferencias de tono y lo que es más importante, las de talante que hubo entre ellos, como se intenta poner de manifiesto en los apartados que siguen.

\section{JULIO ÁLVAREZ DEL VAYO: LA DIPLOMACIA DE APROXIMACIÓN}

La actuación de Julio Álvarez del Vayo como primer embajador en México ha sido calificada por la historiografía como el mejor ejemplo de lo que para Luis de Zulueta, ministro de Estado de la República española 
(diciembre 1931 - junio 1933), debía representar la nueva imagen diplomática del régimen, la diplomacia «discreta» frente a la "secreta», propia de épocas anteriores. Una diplomacia que para él se resumía en un nuevo talante basado en «la psicología del diálogo» 1.

Durante la Dictadura de Primo de Rivera las relaciones con México fueron tensas y los diplomáticos allí destinados no lograron solucionar los contenciosos que aquellas tenían planteados. En los años de la presidencia de Álvaro de Obregón (1920-1924), los representantes españoles no pudieron, ni supieron, hacer frente a la violencia antiespañola, ni vencer la indiferencia de la Administración mexicana ante sus constantes protestas por las expropiaciones sin indemnización de tierras de residentes españoles y por las agresiones a establecimientos comerciales de su propiedad 2 .

La década de los treinta significó para ambos países un intento de cambio en la estructuración de fuerzas políticas a la vez que una reordenación de tipo económico-social. En ese período sus relaciones estuvieron marcadas por varios acontecimientos, entre los que destacan la instauración de la Segunda República y su evolución, y en México, por el continuismo político, ya que los presidentes Pascual Ortíz Rubio y posteriormente Abelardo Rodríguez no fueron más que los portavoces oficiales del verdadero poder ostentado por el general Plutarco Elías Calles (19241928).

México, junto a Uruguay, fueron los primeros países del mundo en reconocer a la República española en fecha tan inmediata como el 16 de abril ${ }^{3}$. Desde ese momento se produjo un giro notable en las tensas relaciones diplomáticas ya referidas, inaugurándose una etapa de distensión y acercamiento especialmente intensos durante los tres años siguientes 4 . La historiografía es coincidente en señalar como motivo

1 Vid. L. DE ZULETA, "La política exterior de la República", Tierra Firme 3 (1935), p. 14.

2. Véanse N. TABANERA, Las relaciones entre España e Hispanoamérica durante la Segunda República española. 1931-1939: La acción diplomática republicana. Tesis doctoral. Valencia, Unv. de Valencia, 1990, pp. 232-235 y "La Segunda República española y México, 1931-1936», Historia 16, núm. 205 (1993), p. 26; C. PANDO, La colonia española en México (1930-1940). Tesis doctoral. Murcia, Unv. de Murcia, 1994, pp. 200-215.

3 Vid. T. G. PowelL, México and the spanish civil war. Alburquerque, Univ. of New Mexico Press, 1981, p. 37; otros dan la fecha de 14 de mayo. Vid. L. LeVerTy, The Spanish cuestion in Mexico: Lázaro Cárdenas and the spanish republicans. Michigan, UMI, 1988, p. 6.

4 Fuentes Mares ha calificado este periodo como "auténtica luna de miel", Vid. J. FUENTES Mares, Historia de dos orgullos. México, Oceáno, 1984, p. 118. La misma idea en Historia de un conflicto. El tesoro del Vita. Madrid, Ed. Cus, 1975, p. 145. 
fundamental del cambio la similitud de los procesos en curso en ambos paises 5 .

Oficialmente este cambio de actitud se concretó en la elevación de las respectivas legaciones a la categoría de embajadas. El Decreto español en el que se basaba esta medida, de fecha de 11 de mayo de 1931, justificaba la misma en su exposición de motivos, alegando que España «libre ya de todo prejuicio atávico e inspirándose en sus gloriosas tradiciones democráticas" debía mantener relaciones con una democracia impregnada de los ideales de paz y progreso como la mexicana, con la que existía además, una íntima compenetración por la "comunidad de origen y unidad de cultura", que imponen el mutuo acercamiento «como un imperativo categórico" 6 .

Julio Álvarez del Vayo y el mexicano Alberto J. Pani, fueron los primeros embajadores. Los discursos pronunciados por Alcalá Zamora, Alberto J. Pani y Pascual Ortíz Rubio en las respectivas presentaciones de credenciales expresan el cambio de orientación que ambos gobiernos querían que adoptase la nueva etapa diplomática. De la retórica propia de estos mensajes se puede extraer el siguiente mensaje: cooperación y reciprocidad dentro de una comunidad de ideales. En frase de Alberto J. Pani: "La Nueva España de ayer, republicanizada, saluda a la Nueva España de hoy" 7.

Como recuerda Álvarez del Vayo en sus memorias, su nombramiento se debió en realidad al gobierno alemán: «Es lo único por lo que le quedé profundamente agradecido" 8 . El Gobierno provisional español lo había designado embajador en Berlín debido a su conocimiento de aquel país. Había estudiado en la Universidad de Leipzig, donde se inscribió en un curso de Historia del socialismo, comunismo y anarquismo. Fue testigo del ascenso militarista previo a la I Guerra Mundial y entabló contacto, entre otros activistas de la izquierda revolucionaria, con Rosa de Luxemburgo. A consecuencia de sus actividades políticas tue expulsado de Alemania ${ }^{9}$.

5 Véanse. G. JACKSON, La República española y la guerra civil Barcelona, Grijalbo, 1976, p. 109; L. Leverty, op. cit;; p. 8 y L. ELWYNn, Mexico and the Spanish republicans. Berkeley, Univ. of California Press, 1955, p. 167.

6 Vid. BOME XLI: 5 (31-V-1931), p. 345. El nombramiento de Vayo tuvo lugar el 17 de mayo. BOME, Ibídem, p. 344.

7 Véanse: Los discursos de Acalá Zamora y Alberto J. Pani en BOME XLI: 7 (31-VII-1931) pp. 518-520. El discurso del Presidente mexicano Pascual Ortíz Rubio se encuentra en el expediente personal de Julio Álvarez del Vayo. Vid AMAE. p. 329, núm. 22964.

8 J. Álvarez del VaYo, En la lucha. Memorias. Barcelona, Grigalbo, 1970, p. 232.

9 La admiración de Julio Alvarez del Vayo hacia Rosa de Luxemburgo llegaria hasta el punto de convertirla en el personaje principal de su única novela publicada, La senda roja. Vid. V. PÉ- 
Con ésta mácula en su currículum, el Gobierno alemán, con el nacionalsocialismo a las puertas del poder, hizo saber al de Madrid que cualquier otro embajador sería preferido al designado. A pesar de las protestas del ministro de Hacienda, Indalecio Prieto, defendiendo el nombre de Vayo, finalmente se llegó al compromiso de elevar al rango de embajada la legación de España en México y nombrarlo para ese puesto 10 .

Álvarez del Vayo y su esposa suiza, Luisa Graa, desembarcaron en Veracruz a mediados de mayo de 1931, comenzando "una de las etapas más felices de nuestra vida" 11. Pero el embajador sabía que la realidad poco tenía que ver con los amables reconocimientos oficiales: «Desde el primer momento supe a lo que venía. A tratar de poner fin a un período de malos entendimientos entre dos pueblos igualmente sensibles al valor personal e igualmente celosos de su independencia (...). No era ciertamente una misión de puro protocolo. La revolución mexicana con su carácter agrario, justo y loable había llegado a herir intereses españoles (...) Las consecuencias eran incidentes por centenares, muertos, reclamaciones, tirantez entre Madrid y la capital mexicana» 12.

En ese momento, la revolución mexicana estaba en su plenitud: reforma agraria, educativa, lucha religiosa. Pero él no tenía intención de dar lecciones, sino de aprender: «Porque quizás puedan deducirse enseñanzas para España, empeñada a estas horas en una empresa revolucionaria semejante", informaba a Luis de Zuiueta al exponerle detalladamente el plan de educación rural mexicano ${ }^{13}$.

El entusiasmo de sus primeros informes y su empatía con la lucha revolucionaria fueron tales que desde el Ministerio de Estado -alertado por Salvador de Madariaga- le llegó un toque de atención que le aconsejaba la prudencia en sus manifestaciones oficiales y personales. Advertencia en consonancia con la imagen de moderación que la República española deseaba transmitir ${ }^{14}$.

El plan de aproximación del embajador iba dirigido en tres direcciones, por un lado a los gobernantes federales, por otro a la colonia española y

REz Plaza, "Julio Álvarez del Vayo. El último olvidado", El exilio /I Col. Biblioteca de la guerra civil V. 19, Barcelona, Ediciones Folio, 1998, p. 95.

10 J. Álvarez del Varo, op. cit.; p. 232; V. Perez Plaza, op. cit.; p. 97.

11 J. Álvarez Del Vayo, op. cit.; p. 231.

12 Ibldem.

13 AMAE. R. Leg 2598. Exp 44.

14 AMAE. R. Log 956. Exp 5. 
por último, al pueblo mexicano, en especial a su componente indígena hacia el que sentía un enorme interés y simpatía.

Para él, la clave de su misión consistía en ganar la cooperación y el apoyo de los mexicanos, presentándoles una España republicana y progresista, enteramente distinta de la España feudal y clerical con la que el México revolucionario no podía entenderse ${ }^{15}$. Pero es aquí donde, en nuestra opinión, se encontraba el punto más conflictivo de su estrategia, ya que esa imagen que lo aproximaba a México corría el peligro de alejarlo de la colonia española que, dominada por elementos conservadores, estaba doblemente resentida, por un lado, con la Revolución mexicana por las razones expuestas y por otro, con la diplomacia de su propio país a la que siempre había visto alejada de sus problemas y, en consecuencia, incapacitada para solucionarlos.

Álvarez del Vayo, para evitar desequilibrios y malentendidos en esa difícil tarea de aproximación, escogió un medio que le permitía el acercamiento simultáneo a esos colectivos tan distintos y tan incomunicados entre sí. Viajó por todos los estados que le fuera posible comprobando de primera mano el grado de antiespañolismo de los mexicanos y el de conservadurismo de los españoles. Para ello tuvo muy claro desde el principio que, dada la estructura federativa de la nación mexicana y la desconexión de propósitos entre el Gobierno central y los federales: «(...) el único camino que se le ofrece a un diplomático activo, es el de ir a los diversos estados y colocarse con los distintos gobernadores en un plano de cordialidad. En general en México cabe esperar mucho más de una amistad conseguida (...), que de todas las reclamaciones oficiales y notas de tramitación puramente formal» 16.

Pero además, Álvarez del Vayo consiguió, no sólo aproximarse, sino establecer una íntima amistad con el general Plutarco Elías Calles. Para ello le visitó en varias ocasiones en su hacienda de Soledad de la Mota, intuyendo que sin su apoyo, la nueva etapa diplomática que él inauguraba sería baldía en la obtención de objetivos concretos, entre ellos, los económicos ${ }^{17}$. Esta amistad personal con Calles no fue la única, y así du-

15 Para dar a conocer la labor transformadora emprendida en España con el advenimiento de la República, Álvarez del Vayo enviaba ejemplares de la Constitución y discursos de Manuel Azaña a políticos, periodistas y bibliotecas públicas mexicanas. Tanto en el Archivo de la FPI como en la parte de su expediente personal que se encuentra en el AGA, existe abundante correspondencia en la que se le agradecen estos envíos. Véanse. FPI. AJB-240-40; AGA. A.E. 16.54/54.03.02.

16 J. Alvarez del Vayo a Lerroux, 2 de octubre de 1931. AMAE. R. Leg. 965. Exp. 5.

17 AMAE. R. Leg 334. Exp 12. 
rante su estancia como embajador: «la Embajada de España que con anterioridad a mi llegada sólo recibía y festejaba a los contrarrevolucionarios, abrió sus puertas a los revolucionarios. La embajada de la República española se convirtió en centro de reunión de los mexicanos que habían hecho directamente la Revolución y continuaban sirviéndola.». Por la legación pasaron personajes esenciales en las futuras relaciones hispanomexicanas, desde el líder sindical Vicente Lombardo Toledano, Narciso Bassols, secretario de Educación, Genaro Estrada, secretario de Relaciones Exteriores y, desde febrero de 1932, embajador en España, Lázaro Cárdenas, secretario de Guerra y Marina, Daniel Cosío Villegas, etc. ${ }^{18}$.

Pero el reverso de la moneda fue que esas amistades le granjearon el recelo y el resentimiento de los miembros de la colonia, haciéndole muy difícil encontrar el equilibrio en ese plan de aproximación a tres bandas. Siendo también criticado por la historiografía conservadora ${ }^{19}$.

El tratamiento concedido a Julio Álvarez del Vayo desde su llegada a México, como él mismo reconocía en sus informes, fue especial respecto al resto del cuerpo diplomático allí acreditado 20 . Esta posición privilegiada, más que una deferencia hacia España, cosa poco probable ya que no se actuó igual con el resto del los embajadores, era el resultado de varios factores, desde sus viajes constantes a sus amistades personales, pero también, a su talante diplomático que le hacía adoptar decisiones que le diferenciaban del resto de sus colegas extranjeros y que no pasaban desapercibidas en los círculos políticos y periodísticos mexicanos, como fue el caso de su postura ante el conflicto religioso, siendo el único miembro del cuerpo diplomático que rehusaba las invitaciones de la jerarquía eclesiástica para asistir a celebraciones que en el fondo eran aprovechadas para atacar la labor reformadora del gobierno 21.

Tras esta labor de acercamiento desplegada en los primeros meses de su estancia en México, Álvarez del Vayo explicaba al ministro de Estado, Alejandro Lerroux, en un telegrama de carácter personal y reservado, los objetivos específicos de su misión diplomática: «Preparado el terreno cerca del gobierno mejicano y de la colonia española, que contra todos los

18 J. Alvarez del Vayo, op. cit.; p. 234.

19 Vid. J. Fuentes Mares, "Historia...", p. 119.

$20 \mathrm{~J}$. Alvarez Jel Vayo a Femando de los Ríos, 9 de julio de 1932. AMAE. R. Leg. 965. Exp. 5.

21 Asi sucedió con la invitación que le cursaron los obispos para asistir a la conmemoración del IV Centenario de la aparición de la Virgen de Guadalupe, evitando aparecer en las críticas que la prensa liberal llevo a cabo sobre los demás representantes del cuerpo diplomático. Vid. J. Alvarez del Vayo a L. de Zulueta. 12 de enero de 1932, AMAE. R. Leg. 334. Exp. 12. 
augurios de dificultades, se ha puesto decididamente a mi lado, juzgo llegado el momento de rogar a Vuecencia someta de considerarlo oportuno a la consideración del gobierno, un plan de acción combinada, destinada a encauzar la amistad hispano-mexicana hacia resultados prácticos inmediatos. Habría que abordar simultáneamente, como partes inseparables de una misma acción diplomática, las tres cuestiones fundamentales: Reclamaciones, ley de Trabajo ayer aprobada, y confección de un Tratado de Amistad y Comercio entre España y México que no existe" 22.

A la altura de 1931, el principal contencioso entre ambos países era el de las reclamaciones de los españoles por los daños sufridos durante la Revolución. El embajador envió una serie de informes al Ministerio de Estado en los que exponía, cúal debía ser a su juicio la estrategia diplomática a seguir en este asunto por parte española. El plan de Álvarez del Vayo era completamente innovador y rompía el ineficaz marco de actuación anterior 23. Desde que en 1925 ambos países firmaran un Convenio a fin de crear una Comisión Mixta que resolviese el asunto, lo único que se había logrado era conducir las negociaciones a un punto muerto.

El embajador abogaba por sustituir la búsqueda de una solución basada en el derecho, por una solución política de «amplio horizonte histórico". Es decir, que en lugar de negociar para determinar la cantidad global a cobrar, lo que a su juicio había que hacer era renunciar a ese monto y presentar a México la renuncia como un gesto acorde con el talante de la nueva etapa y especialmente como un gesto generoso de la República española, que aun con dificultades económicas, ayudaba a la también débil economía mexicana, en la certeza de que México sabría corresponder con creces. Las ventajas que Álvarez del Vayo preveía iban desde la supresión de la ley del Trabajo que perjudicaba seriamente a los españoles ${ }^{24}$, hasta la firma del acuerdo comercial y de arbitraje, y lo que

22 Este telegrama no aparece en la documentación manejada, pero Alvarez del Vayo recupera su contenido fundamental en el informe reservado dirigido a Lerroux el 7 de septiembre de 1931 con ocasión del asunto de las reclamaciones. AMAE. R. Leg. 512. Exp. 30.

23 Alvarez del Vayo envió al Ministerio de Estado varios informes sobre el tema de las reclamaciones. AMAE. R. Leg. 512. Exp. 30.

24 La promulgación en agosto de 1931 de la Ley Federal del Trabajo ó "Ley del 90" obligaba a los empresarios mexicanos a contar al menos con un $90 \%$ de trabajadores nacionales. Para los españoles no parecía existir más salida que la naturalización o el abandono del país. Con la llegada de Vayo, las autoridades encargadas de velar por su cumplimiento hicieron la vista gorda para no perjudicar a los españoles, a pesar de los graves problemas que en ese momento planteaba el desempleo. Véase. N. TABanera, "La Segunda República y...", pp. 26-27; J. Fuentes MARES, “Historia de..., p. 120. 
era fundamental para el prestigio de España en la zona de cara a su máximo competidor, la medida condenaría a los Estados Unidos a continuar durante años el antipático papel de ser el único gran reclamante.

El Ministerio de Estado no comprendió la propuesta de Vayo: «Más bien reaccionó, (...), cual si se hallase ante una iniciativa pueril, inexperta, de censurable e incomprensible ligereza» 25.

J. López Oliván, en ese momento Director de la Sección de Política del Ministerio, le «aconsejó desde un punto de vista moral», no renunciar a las indemnizaciones ya que esa decisión supondría dejar abandonados a los españoles a los que precisamente él, como embajador, tenía la obligación de darles protección diplomática. En este sentido le instaba a mantener como representante de España, una postura firme y no ceder ni un palmo en esta cuestión, sin haber antes obtenido una compensación, no en forma de promesa, sino en hechos reales y concretos 26.

Álvarez del Vayo olvidó su propuesta y de acuerdo con las recomendaciones del Ministerio consiguió avanzar en las negociaciones al obtener la conformidad del gobierno de Azaña para firmar un acuerdo confidencial y secreto por el que México se comprometía a pagar una cantidad global de cuatro millones de pesetas 27.

Seria aventurado decidir, en base a la documentación manejada, quién llevaba razón en este asunto. Lo que sí se puede afirmar es que al menos, en su totalidad, los pagos no se efectuaron y este contencioso fue heredado por los sucesivos embajadores españoles y continuaría sin resolverse durante el franquismo, ya que dada la ausencia de relaciones diplomáticas oficiales no se consideró oportuno hacer ningún intento en este sentido 28.

El éxito tampoco acompañó a las negociaciones para la firma del Tratado Comercial y de Amistad. Hay constancia de ellas desde septiembre de 1931. En el transcurso de las mismas se puso en marcha un complicado mecanismo en el que intervenian los Ministerios de Estado, Hacienda, Economía e Industria. Por otra parte, se recogió información de la embajada, consulados y de las cámaras de comercio españolas sobre determinados aspectos del futuro convenio. Del mismo modo, los responsables

25 J. Álvarez del Vayo a L. de Zulueta, 10 de mayo de 1932. AMAE. R. Leg. 520. Exp. 30.

26 Informe de J. López Oliván a M. ${ }^{\circ}$ de Estado, Madrid, 10 de agosto de 1931, AMAE. R. Leg 512. Exp.30.

27 M. Azaña a Álvarez del Vayo, Madrid, 1 de febrero de 1932, AMAE. R. Leg. 510. Exp. 30.

28 Vid. N. Tabanera, "Las relaciones...", p. 275. 
mexicanos recabaron información similar a sus representantes. Hay que destacar el interés con el que las negociaciones fueron seguidas por parte de los pequeños productores y empresarios españoles, quienes enviaron a la embajada informes, algunos francamente ingenuos en sus análisis de mercado, con la intención de promocionar la distribución de sus productos 29 . El Tratado de Amistad y Comercio no fue firmado.

Por el contrario, la concreción de intereses y la rapidez en las negociaciones se impusieron en la firma el 14 de febrero de 1933 de un Convenio Naval entre ambos países, en el que México acordaba la compra de cinco cañoneros y diez lanchas patrulleras que se construirían en astilleros españoles 30 .

En noviembre de 1932 se desplazó a México una Comisión Naval Española, para negociar con su homóloga mexicana, llegando el asunto a interesar al propio Calles cuya amistad con el embajador no es de extranar que influyera positivamente en el resultado final. Las negociaciones no fueron fáciles, las ofertas de otros países -Japón, Italia, Alemania, Gran Bretaña y Estados Unidos- ya se habian estudiado, y hubo reacciones negativas de sus gobiernos, al considerar el proceso como una muestra del favoritismo hacia España. A su vez, en ambos países, el Tratado adquirió el carácter de simbolo de las nuevas relaciones que se convirtieron en el ejemplo de lo que debía ser el hispanoamericanismo eficaz: «(...) si España ha de emprender una política hispano-americana eficiente, ha de ser en México donde se inicie por afinidad racial y política, por su riqueza natural y situación, y por ser la única que ha opuesto resistencia salvaje a todos los halagos y presiones del exterior, mostrándose como la verdadera frontera del Hispano-Americanismo» 31.

Al mismo tiempo, las Cortes españolas aprobaron por unanimidad, el 28 de diciembre de 1932, una ley por la que se concedia a México un crédito de 70 millones de pesetas, destinado al pago de los barcos, que era precisamente el asunto que más había preocupado a la Comisión mexicana. Los parabienes y felicitaciones mutuas inundaron de discursos las

29 AGA. AE. 54/Leg 614, y correspondencia privada de Alvarez del Vayo AGA. AE. 16.54/54.03.02.

30 Los orígenes del Tratado se encuentran en la misión encomendada al comandante de artillería Eduardo Orduña, en agosto de 1924, con el fin de difundir la industria española en Cuba, EE.UU, México, Venezuela, Colombia y Perú. Vid. N. Tabanera, "La Segunda República y...", p. 30.

31 Comisión Naval a México. Informe resumen de las negociaciones. Estrictamente confidencial. AMAE. R. Leg. 964. Exp. 2. 
Cámaras legislativas y la prensa de ambos países: “(...) y por primera vez desde que Méjico es independiente, se oyeron en su Parlamento repetidas vivas a España y a su Gobierno republicano» 32.

La Comisión Naval española elogió el papel desempeñado por la embajada de nuestro país y por Álvarez del Vayo: «(...) pudimos darnos perfecta cuenta de la extraordinaria labor desarrollada por nuestra Embajada, y de la situación excepcional que ha llegado a ocupar en aquel país que hará no sólo factible, sino fácil, cualquier gestión de aproximación» 33.

Como es de suponer en una operación de esa envergadura llevada a cabo entre dos estados con serias dificultades financieras -en un clima mundial de depresión económica- las críticas fueron simultáneas a los elogios. La opinión pública mexicana consideró el Convenio completamente oneroso para el país. En concreto no vio con buenos ojos el hecho de que los barcos se construyeran en España, ya que esta parte del acuerdo les privaba de los puestos de trabajo correspondientes y lejos de ser una fuente de ingresos, implicaba la salida de capitales. Los grupos hispanófobos, entre ellos uno denominado R.E.M. (Reintegración Económica Mexicana), aprovecharon la situación y organizaron una campaña antiespañola en la que se repartieron grandes pasquines en zonas claves del país con un texto en el que aparecía como chivo expiatorio Álvarez del Vayo, al que se acusaba de fomentar la hispanofilia y, lo que probablemente más le dolería como embajador, su contribución a engrandecer «el botín de la Conquista» 34 .

Paralelamente España, ante sus limitadas posibilidades económicas en la zona, utilizó la vía cultural como vehículo político para ejercer su influencia "espiritual» en Hispanoamérica y lógicamente, en México. En relación a єste país, los intercambios culturales también se beneficiaron de la apertura ideológica, amoldándose en cualquier caso a las restricciones presupuestarias y a los prejuicios antiespañoles, bastante justificados en ocasiones, que permanecian en ciertos sectores mexicanos.

Hasta la llegada de Álvarez del Vayo, era opinión común de nuestros diplomáticos que el indigenismo de los mandatarios mexicanos se hacía en ocasiones incompatible con el respeto debido a España como nación

32 AMAE. R. Leg. 964. Exp. 1; AGA. AE. 54/54.03.02.

33 Ibídem.

34 AGA. AE. Leg. 627. En el año 1947, la prensa franquista utilizaría este contrato contra el exilio republicano. Vid. El Español, 3 de mayo de 1947. 
amiga, explicándose así que fueran frecuentes sus protestas ante manifestaciones injuriosas de organismos públicos, personalidades y artistas contra el pasado colonial español o contra la historia y cultura española. El caso más paradigmático y sin resolver en 1933, era el de las pinturas que Diego Rivera hizo en el palacio de Hernán Cortés de Cuernavaca (Morelos). En ellas, además de la particular visión de la Conquista española por parte del artista, "pintor mestizo y bolchevique», se unía como agravante que el encargo y la financiación de la obra provenían del «opulento e inquieto" embajador de Estados Unidos en México, Dwight Morrow, circunstancia en la que se veía claramente, a juicio del Ministro Plenipotenciario de España, Vizconde de Gracia Real, la conspiración del vecino del Norte para desprestigiar a nuestro país, no ante los mexicanos "descendientes de los indios bravos de la época de Moctezuma» cuya opinión parece ser que no importaba mucho, sino de la «opinión mexicana sensata que es inmensa mayoria» ${ }^{35}$.

El nuevo embajador intentó una solución basada en el consenso y en el respeto al pasado histórico de ambos países. Conforme a ello, y de acuerdo con el gobernador del estado de Morelos, Vicente Estrada, idearon la superación de este contencioso, por otra parte, azuzado por la prensa conservadora española, levantando un monumento a la amistad y cooperación hispano-mexicana ${ }^{36}$. El desinterés que provocó el proyecto y la falta de presupuesto, lo redujo a una mera declaración de intenciones.

A pesar de ello, se obtuvieron otros éxitos potenciando el intercambio cultural entre instituciones académicas, propiciado en los primeros años por el Instituto Hispano-Méxicano de Intercambio Universitario, subvencionado por el Ministerio de Estado desde 1930 a 1932, y continuado después por la Junta de Relaciones Culturales con su Plan de Expansión Cultural en Hispanoamérica, aprobado en 1933.

Hay que mencionar igualmente, la inauguración el 4 de marzo de 1933 de la Casa de Estudios Hispano-Americanos de México, hecho de suma importancia para los mexicanos «porque cuando se penetra en el estudio de la psicología del pueblo mexicano y cuando se quiere encontrar la raíz y el fundamento de su carácter se tropieza fatalmente con lo español» 37 .

35 Vizconde de Gracia Real a M..$^{\circledR}$ de Estado, 7 de diciembre de 1930, AMAE. R. Leg 965. Exp. 5.

36 J. Álvarez del Vayo a L. de Zulueta, 1 de marzo de 1933, AMAE. R. Leg 962. Exp. 11.

37 Párrafo extraído del discurso pronunciado el día de la inauguración por el Licenciado Luis Chico Goerne, miembro del consejo consultivo. AMAE. R. Leg. 1251. Exp. 36. 
Álvarez del Vayo hizo todo lo que estuvo en sus manos para que los mexicanos tuvieran otra imagen de España y de los españoles alejada de visiones atávicas negativas. A diferencia de sus antecesores que tendieron con sus actitudes a marcar distancias, él buscó la proximidad, y así, si para conseguir el acercamiento político enviaba a organismos públicos, colegios y bibliotecas ejemplares de la Constitución y discursos de Manuel Azaña, para conseguir el acercamiento cultural solicitaba al Ministerio de Estado el envío a la embajada de libros de autores españoles especialmente de literatura, historia y filosofía, para luego él distribuirlos en ateneos, universidades, escuelas, etc. ${ }^{38}$.

Julio Álvarez del Vayo presentó su dimisión como embajador en México el 30 de septiembre de 1933 debido a la caída del tercer Gabinete Azaña y la formación de un nuevo gobierno a cargo del radical Lerroux sin la presencia del Partido Socialista. Tras el reconocimiento de la URSS por el gobierno republicano, éste nombra a Vayo primer embajador de la República en dicho país. Nunca llegaría, sin embargo, a ocupar su cargo ya que antes de tomar posesión del mismo, las elecciones a Cortes de noviembre de 1933 daban la victoria a la coalición Lerroux-CEDA.

La embajada de Julio Álvarez del Vayo significó el período de mayor sintonía diplomática entre ambos países. Quedaron varios e importantes asuntos sin resolver, indemnizaciones, cuestiones económicas y mutuos prejuicios sobre la historia común. A pesar de ello, su personalidad marcó de manera determinante el futuro de las relaciones España-México sin que aparentemente muchos de sus proyectos estuvieran dirigidos desde Madrid. Su influencia en el escenario mexicano no dejó de estar presente a lo largo de todo el período que estudiamos, y de hecho se ha visto en ella y en sus amistades personaies en especial con Lázaro Cárdenas uno de las razones del apoyo mexicano a la causa republicana en los duros años de la guerra civil, en los cuales Vayo sería titular de la cartera de Estado en dos ocasiones, dei 4 de septiembre de 1936 al 17 de mayo de 1937, y desde el 6 de abril de 1938 hasta el final de la contienda.

\section{AÑOS DE DESENCUENTRO}

Desde la dimisión de Julio Álvarez del Vayo hasta la llegada a México como embajador de Félix Gordón Ordás, en mayo de 1936, transcurren

38 AMAE. R. Løg. 1251. Exps. 34 y 37 
unos años en los que tienen lugar acontecimientos claves en la política interior de ambos países. La circunstancia de que estos cambios, desde el punto de vista ideológico no fueran tan acordes como los que hubo en los años precedentes, tuvo sus lógicas repercusiones en el ámbito diplomático.

A pesar del mutuo empeño de dar a las relaciones hispano-mexicanas una imagen externa de "cordialidad", heredera del talante introducido por Álvarez del Vayo en México y de Genaro Estrada en España, el desencuentro diplomático resultó en algunos casos inevitable.

Un decreto de 18 de diciembre de 1933, nombraba a Domingo Barnés Salinas, hasta entonces ministro de Instrucción Pública, embajador de España en México, presentando sus credenciales el 24 de enero de 193439.

Al poco tiempo de su llegada a México, el nuevo embajador era testigo del inicio de la campaña electoral que llevaría a Cárdenas a la presidencia de la República. Para él, las elecciones de 6 de julio de 1934 fueron: "...las más tranquilas de México desde hace muchos años...", y mostraba su sorpresa de que el ejercicio del sufragio en las mismas: «... a la manera en que se entienden y practican en México...", no hubieran registrado las clásicas notas sangrientas, aunque en su opinión, el nuevo presidente estaba condenado a ser un «prisionero político» del general Calles ${ }^{40}$. Aunque la primera parte era cierta y la segunda poco acertada, hay que decir que el tono del diplomático denotaba una cierta condescendencia hacia el carácter «poco civilizado» del pueblo mexicano.

Para Barnés el objetivo de sumisión diplomática, tal y como dejaba traslucir en sus informes, era mantener una actitud lo más discreta y conciliadora posible evitando conflictos innecesarios. En uno de sus mensajes a Madrid, en los que daba cuenta de diversos actos a los que había asistido con la finalidad de afianzar las relaciones hispano-mexicanas, se puede leer el siguiente párrafo: «Se asocian en este informe todos estos asuntos porque ninguno tiene un excepcional y peculiar relieve y porque todos ellos no son sino una expresión de la actividad modesta, pero bien intencionada, que esta Embajada viene realizando y muy especialmente en éstos últimos tiempos en los que era importante evitar que la relativa discrepancia en el tono y en el acento con que la política de ambas repúblicas se desenvuelve, pudiera rozar ni enfriar en nada el ambiente de

39 AMAE. P. 321. núm. 22. 733; AGA.AE. 22.54/54. 03.02

40 Domingo Barnés a M. de Estado, 6 de julio de 1934. AMAE. R. Leg. 965. Exp. 14 
simpatía y cordialidad con que se llevan, por fortuna, las relaciones entre ambos países ${ }^{41}$.

En este sentido, se puede afirmar que este embajador proyectó hacia la opinión pública mexicana una imagen conciliadora de la que quiso hacer partícipe a la siempre recelosa colonia española. Este talante le fue reconocido tanto por el secretario de Relaciones Exteriores, José Manuel Puig Casauranc, como por la mayoría de la prensa mexicana 42.

Por lo que respecta a la organización de la embajada, un mes antes del regreso de Barnés a España, Ramón María de Pujadas comenzó a desempeñar el cargo de primer secretario de la embajada, asumiendo también las funciones de encargado de negocios a.i. hasta la llegada del nuevo embajador, Emiliano Iglesias, el cual fue nombrado por decreto el 29 de marzo de 1935 y presentó sus credenciales ante Cárdenas el 30 de septiembre de ese mismo año ${ }^{43}$.

En la documentación existente en el AMAE, hay un informe, de ese mismo dia, en el que el embajador expone al Ministerio de Estado las líneas básicas de su acción diplomática:. "México puede y debe ser el nexo para una gran política americanista de habla española. (...) Esta es la hora propicia. He tenido la fortuna de llegar en ella (...)". Los escollos que veía para lograrlo eran tres. El primero, la situación de la colonia española, «fraccionada, dividida y en forcejeos impropios de su ciudadanía y de su función patriótica". En segundo, las malas relaciones que la embajada había tenido hasta el momento con la prensa mexicana, en especial con la conservadora: Excélsior, El Dia, Todo, a su juicio la más influyente, lo que atribuía al "criterio absurdo de sus antecesores de cortar el contacto con elementos de significación política distinta». El tercer obstáculo, y en el que incidiría en sucesivos informes, era la escasez de emolumentos que recibía la embajada para gastos de representación ${ }^{44}$.

Tanto para él como para Ramón Maria de Pujadas, el españolismo y el anticomunismo constituyeron dos puntos de vista a través de los cuales la realidad mexicana fue transmitida al Ministerio de Estado. La formación

41 Domingo Barnés a M. ${ }^{2}$ de Estado, 11 de mayo de 1934, AMAE. R. Leg. 965. Exp. 5.

42 La carta de agradecimiento de J. M. Puig Casauranc aparece como anexo al informe del embajador. AMAE. R. Ibídem.

43 AMAE. P Leg. 310. núm. 22. 412; AGA. AE. 9. 54/ 54.03.02.

44 Emiliano Iglesias a M..$^{9}$ de Estado, 30 de septiembre de 1935. AMAE. R. Leg. 962. Exp. 9. La llegada del embajador coincidió con una restricción de las dotaciones del Ministerio hacia las !egaciones españolas, principalmente las hispanoamericanas. Vid. N. TABANERA, "Las relaciones...", pp. 118-121. 
del nuevo gabinete presidencial, la intensificación del conflicto religioso, la reforma de la educación, el auge del movimiento obrero y la expulsión del general Calles, fueron entre otros, los temas que centraron sus informaciones.

La mayoría de los miembros del gabinete presidencial fueron objeto de análisis. Al poco de llegar a la embajada Emiliano Iglesias, le llamó la atención «la intensa campaña a favor de Rusia del líder obrero Lic. Vicente Lombardo Toledano, que acababa de regresar de aquél país, prodigando en mitines y artículos de prensa los más cálidos elogios sobre los beneficios que reporta la implantación del régimen comunista", aunque el presidente del PNR (Partido Nacional de la Revolución), Emiliano Portes Gil, «condenaba cualquier intento de implantación en México del régimen comunista", y que la opinión pública general "condenaba cada día más las extravagancias del Lic. Lombardo Toledano y su esfuerzos por convertir este país en un feudo de la URSS» 45 . Temor, que era común a la derecha española respecto al futuro inmediato del nuestro.

Por su parte, Pujadas mostraba sus reticencias hacia Portes Gil. Informando al Ministerio de Estado a cerca del libro escrito por el presidente del PNR, bajo el título La lucha entre el poder civil y el clero, en el que reseñaba: «...El libro del Sr. Portes Gil no añade nada nuevo en orden a sus ideas políticas respecto a los problemas actuales mexicanos, y de sus ataques a la obra de España en el pasado no puede deducirse que sea antiespañolista (...) en su actuación pública no es ni españolista ni antiespañolista. (...) Indio puro, educado en un ambiente mexicano (...) si fuese españolista no podría demostrarlo ocupando altas funciones de Gobierno, pues prescindirían enseguida de él. (...) Sometido a esas presiones e influencias, es imposible que un alto funcionario se declare españolista, $y$ los que lo son en el fondo por su origen español (..), cuando ocupan funciones del Gobierno, prescinden de sus sentimientos y siguen la corriente que no puede decirse en general sea muy a favor de España» 46.

Durante este periodo, el clima antiespañol, alentado por la prensa conservadora mexicana, fue en aumento y alcanzó cotas importantes cuando el diario Excélsior en su editorial de 14 de noviembre titulado Españolismo y antiespañolismo denunciaba que determinados libros de texto, editados por la Secretaría de Educación Pública, incluian unos ejercicios de

45 Emiliano Iglesias a M. ${ }^{2}$ de Estado, 4 de diciembre 1935. AMAE. R. Leg. 969. Exp. 9.

46 Ramón M. ${ }^{8}$ de Pujadas a M. ${ }^{2}$ de Estado, 26 de marzo de 1935. AMAE. R. Leg. 962. Exp. 9 
historia que, según el diario, constituian verdaderos ataques a las relaciones cordiales de México con España. De forma inmediata Emiliano Iglesias envió una nota de protesta y consiguiente petición reparadora al secretario de Relaciones Exteriores, Eduardo Hay, quien de forma escueta contestaba: “(...) Se han solicitado de las autoridades competentes, los informes relativos a fin de considerar el alcance de tales conceptos y proceder en su caso con la debida equidad» 47. Aún así, el embajador insistió en el asunto en varias ocasiones.

Precisamente, la equidad como regla básica de la diplomacia, era aludida frecuentemente en los informes que el segundo embajador mexicano en nuestro país, Genaro Estrada, enviaba al secretario de Relaciones Exteriores, J. M. Puig Casaurant.

La labor de Genaro Estrada en España transcurrió, desde el 21 de enero de 1932 hasta el 23 de octubre de 1934. Traía consigo una dilatada experiencia, no solo diplomática, sino también como político, historiado y escritor. Fue sin duda una de las personalidades clave en las relaciones exteriores de esa nación en una década - la de los treinta- en la que compartió responsabilidades con otros compañeros tan significados como Isidro Fabela, Alfonso Reyes, Daniel Cosío Villegas, Luis Padilla Nervo... Todos ellos protagonizaron el que fue sin duda uno de los periodos más brillantes de la diplomacia mexicana. Su acción conjunta consiguió por primera vez la autoafirmación de México como nación en los foros internacionales. Punto de referencia obligado en esta etapa fue la declaración que Genaro Estrada entregó a los diarios de la Ciudad de México el 27 de septiembre de 1930, y que se convirtió en un documento histórico conocido como la Doctrina Estrada.

Este embajador fue testigo excepcional de una parte del transcurrir de la Segunda República española. Su afirmación de que «El diplomático debe ser, en este sentido, como un conjunto de los ojos, el oído y la conciencia de un país, destacados en otro país" 48.

Desde antes de su llegada comprendió que la Segunda República constituía una oportunidad histórica para estructurar en nuestro país un estado democrático.

47 El editorial del Excélsior, la nota de Iglesias a Eduardo Hay y la respuesta de este, en AMAE. R. Leg 2598. Exp. 44.

48 Correspondencia privada de Genaro Estrada. Carta personal a J. M. Puig Casauranc, 13 de junio de 1934. AHDM (Archivo Histórico Diplomático Mexicano), Genaro Estrada: La diplomacia en acción, México DF, Secretaría de Relaciones Exteriores, 1987, p. 236. 
Dos cuestiones acerca del nuevo régimen centraban la información que demandaban los responsables de la diplomacia mexicana a su embajador: la estabilidad del mismo y su capacidad para sacar adelante su programa democrático. En uno de sus primeros informes, Estrada, tras acudir a una de las sesiones del Congreso que iniciaba el debate sobre la reforma agraria, escribía: «(...) El jefe de gobierno, conoce a su gente y conoce el alcance de todos y cada uno de los políticos de la hora actual. Sabe que neutralizado el peligro militar (...) el gobierno puede avanzar sin graves cuidados. El discurso de Azaña es un modelo de habilidad política y de habilidad parlamentaria. Su principal mérito es el del sentido común, que es también el principal mérito de su autor» 49.

En agosto de 1933 -tras la crisis gubernamental de julio-, y estando de vacaciones en San Sebastián, el embajador informa, en nota reservada, del cerco de la prensa conservadora española contra el gobierno republicano ${ }^{50}$, y de las repercusiones de este hecho en las relaciones entre ambos países. Por estas fechas se produjo un cambio en el Consejo de Redacción del diario liberal, afín al gobierno, El Sol. Ante este hecho, Estrada informaba lo siguiente: «(...) ahora que E/ Sol ha pasado a otras manos, se ha suprimido de plano la sección hispano-mexicana y con ellas las noticias de México proporcionadas por la agencia Trens ${ }^{51}$, y las que transmitia esta embajada, con lo cual esta dicho que como no vamos a tener la hospitalidad de los otro dos grandes diarios enemigos de México, o sea $E I$ Debate, órgano de los jesuitas y $A B C$, órgano de los monarquistas, nos hemos quedado en España sin prensa (...)" 52.

El cambio de tono en las relaciones entre ambos países, tras un periodo de entendimiento, había comenzado. El ataque a la República por parte de los grupos conservadores incluía la hostilidad hacia los gobiernos extranjeros que la apoyaban, y en este sentido, México y su repre-

49 Genaro Estrada a J. M. Puig Casauranc, 9 de junio de 1932, ibidem, p. 133.

50 Sobre las relaciones entre la prensa y el gobierno de Manuel Azaña, en el momento al que se refiere Estrada en su informe, Vid. J. AviLÉs FARRE, La izquierda burguesa en la Segunda República. Madrid, Espasa-Calpe, 1985, pp. 190-191.

51 La agencia de noticias Trens, fue creada a instancia de Genaro Estrada en 1930, para contrarrestar las informaciones tendenciosas que sobre México difundian las norteamericanas United Press y Associated Press, así como también, de algunas europeas. Las noticias a través de la agencia Trens eran transmitidas desde México (Chapultepec), a dos estaciones receptoras, una en Chile (Valparaiso) y otra en España (Bilbao). Desde estos dos puntos la información era transmitida a las legaciones mexicanas en Europa, América del Sur y Central. Vid. J. FLoRES, "Genaro Estrada y su labor diplomática», en AHDM, Genaro Estrada: diplomático y escritor. México, Secretaría de Relaciones Exteriores, 1978, p. 35.

52 Genaro Estrada a J. M. Puig Casauranc, 3 de agosto de 1933, ibidem, p. 180. 
sentación diplomática, constituían el blanco perfecto de la propaganda reaccionaria.

Tras las elecciones de noviembre de 1933, Genaro Estrada resumía claramente al secretario de Relaciones Exteriores la situación: “(...) Entre nuestra mentalidad revolucionaria y ésta, abrumada de distingos y de racionalismos, median abismos de psicología social. Las comparaciones que de cuando en cuando aparecen por ahí entre los hechos de uno y otro país y sus modos de operar, no pasan de inocentes sentimentalismos, del todo ajenos a la verdad (...) $) 53$.

Al mes de enviar la información anterior, el embajador confirmaba definitivamente el carnbio en las relaciones entre ambos países: «(...) Mientras tanto -la pregunta es interesante sólo para nosotros-, ¿qué recibimos o qué esperamos de esta situación en España? Respuesta: no recibimos nada hasta ahora; lo damos casi todo con nuestras un poco inexplicables largueza y generosidad. Nuestra excelente situación de simpatía que habíamos logrado aquí con los gobiernos anteriores, sólo significa aquí, en política, la simpatía de un grupo de socialistas (...) desaparecidos los socialistas (...) no podemos esperar que continúen las mismas consideraciones oficiales, ni siquiera la platónica a la que veníamos acostumbrándonos (...). Estamos -y debemos reconocerlo cara a cara- dentro de un paréntesis, sin simpatía, sin eco y sin provecho para nosotros en nuestras relaciones con España. Nos queda el derecho, un poco metafísico, de desear fervorosamente que este paréntesis se cierre a la mayor brevedad posible» 54 .

Sin embargo, el paréntesis lejos de cerrarse se abrió. El 13 de abril de 1934, la embajada mexicana, situada en la calle Hermanos Bécquer de Madrid, sufrió un atentado. El enojo de Estrada ante estos acontecimientos se refleja en los sucesivos informes. Sin embargo, el embajador reconocía, sin ningún género de dudas, que incluso en esos momentos: "se vive una vida pública de libertad y se respetan las libertades individuales. Esto hace que cualquier propósito de violencia esté siempre neutralizado por la libertad política, social y legal que se disfruta” 55 .

Igualmente, Estrada reconocía al secretario de Relaciones Exteriores que en los círculos no oficiales, en los centros de cultura y dentro de determinadas instituciones oficiales, la afiridad con México continuaba existien-

53 Genaro Estrada a J. M. Puig Casauranc, 26 de febrero de 1934, ibídem, p. 208.

54 Genaro Estrada a J. M. Puig Casauranc, 26 de marzo de 1934, ibidem, pp. 216-217.

55 Genaro Estrada a J. M. Puig Casauranc, 26 de marzo de 1934, ibídem, pp 230-233. 
do. Así por ejemplo, recibió con agrado la invitación que le hizo, el Museo Nacional de Artes Decorativas - dedicado exclusivamente a la exhibición de arte español-para organizar una exposición de arte popular mexicano 56.

En junio de 1934, el embajador enviaba una carta privada a Puig $\mathrm{Ca}$ sauranc. En ella expresaba su deseo de viajar a México en el mes de octubre, dejando entrever la posibilidad de no regresar, alegando varias razones: La primera, los problemas de salud de su madre y de su hija; la segunda, el cambio de gabinete que se iba a producir en su país en el mes de diciembre a consecuencia de las elecciones de septiembre y que obligaba, a todo el cuerpo diplomático mexicano, a dimitir; la tercera, su intención de renunciar definitivamente a la carrera diplomática. Aunque no lo dijera, la razón fundamental era su propia enfermedad, de la que moriría en septiembre de 1937.

A parte de esto, en la misma carta, Estrada hacia una reflexión final acerca del futuro de las relaciones hispano-mexicanas. Ante todo, aconsejaba a los responsables de las mismas «distinguir entre lo eventual y lo permanente». Para Estrada, lo que había que dejar "en punto muerto» eran las diferencias políticas coyunturales y los tópicos recíprocos que distorsionaban la realidad. Frente a ellos, había que oponer «la obra común y de simpatía entre el México revolucionario y la España nueva que nació en $1931 » 57$.

En enero de 1935, Cárdenas nombraba a Manuel Pérez Treviño, nuevo embajador en España. Tanto su designación como su destitución, estuvieron, y siguen estando, envueltos en la polémica. Según José Antonio Matesanz, Cárdenas empezó a utilizar las embajadas como una especie de exilio prestigioso para políticos importantes cuya presencia en el país no le era grata 58 . Treviño cumplía ese requisito y, además, había sido su contendiente en las elecciones, dentro del propio partido oficial. La afirmación de Matesanz encuentra apoyo en un informe que en enero de 1936 envió a Madrid Ramón M. ${ }^{a}$ de Pujadas, tras una conversación con el jefe de Asuntos Políticos de la Secretaria de Relaciones Exteriores, en la cual afirma que éste le había comentado que la posición de Treviño en España no era sólida y que desaparecidas las razones que aconsejaban

56 Genaro Estrada a J. M. Puig Casauranc, 17 de noviembre de 1932, ibídem. pp. 243-244. La exposición no se llegó a realizar debido a que la Secretaría de Educación no concedió a la de Exteriores, los fondos necesarios. Vid. Informe de Genaro Estrada de 24 de marzo de1933, ibidem, pp. 245-247.

57 Genaro estrada a J. M. Puig Casauranc, 13 de junio de 1934, ibídem, pp. 235-242.

58 Vid. J. A. MATESANZ, "Las raices ...", p. 32. 
su designación y alejamiento del país, una vez afianzado Cárdenas en el poder, no sería extraño que fuese sustituido ${ }^{59}$. Efectivamente, Cárdenas sustituyó a Pérez Treviño en 1937 por Ramón P. De Negri.

Por lo que respecta a la diplomacia española en México, Emiliano Iglesias presentó su dimisión como embajador desde Pontevedra en febrero de 1936, días antes del triunfo del Frente Popular, siendo nombrado en su lugar Félix Gordón Ordás.

\section{FÉLIX GORDÓN ORDÁS: LA DIPLOMACIA DE GUERRA}

Cuando Félix Gordón Ordás llegó a la capital mexicana, el 29 de mayo de 1936, en su primera rueda de prensa hizo una declaración institucional de lo que serían sus proyectos en la embajada. Además de trabajar intensamente porque las relaciones entre ambos países fueran cada vez más estrechas y dar a conocer la verdadera situación de la República Española, el embajador iba a abordar dos cuestiones muy concretas, la firma definitiva del tratado comercial, cuyas negociaciones había iniciado Álvarez del Vayo, y un asunto de engañosa frivolidad, pero fuertemente politizado por la derecha de ambos países: el problema creado por la negativa de los toreros españoles a alternar con sus colegas mexicanos en España. Como dice en sus memorias, "el huracán de la guerra», que estallaba mes y medio después, le obligaron a llevar adelante un programa muy distinto 60 .

El impacto del conflicto, en la ya de por sí poco republicana diplomacia española, provocó su escisión definitiva. La configuración de esta doble diplomacia, mayoritariamente adherida a la Junta de Defensa Nacional, no facilitó el trabajo de los representantes que se mantuvieron al lado del Ministerio de Estado. Éstos tuvieron que actuar sin apenas instrucciones, demandando una información que no liegaba o que llegaba a destiempo, y enfrentándose a la vez a las deserciones que se producían en su legación y a las reacciones ideológicas de los gobiernos y de las sociedades civiles de los países ante los que se encontraban acreditados ${ }^{61}$.

59 Ramón M..$^{2}$ de Pujadas a M. de Estado. 19 de enero de 1936, AMAE.R. Leg. 962. Exp. 10.

60 Estas declaraciones están recogidas en el diario Excélsior de 29 de mayo de 1936, y son fielmente transcritas por Gordón Ordás en F. Gordón ORDAs, Mi política fuera de España, T. I. México, Imprenta Victoria, 1965, pp. 142-143. La cita en p. 180.

61 Un estudio del impacto de la guerra civil en la diplomacia española en Europa en, M. CASANOVA, op. cit.; pp. 27-36. Sobre sus repercusiones en la diplomacia española en Hispanoamérica, en N. TABANERA, "Las relaciones...", pp. 440-532. 
En México las cosas no fueron distintas. La solidaridad y el apoyo del gobierno y de su presidente Lázaro Cárdenas pudo ayudar a crear un ambiente algo diferente al que se acaba de aludir, pero éste duró poco tiempo. El México cardenista no era homogéneo ni en lo social ni en lo político. La guerra civil española, constituyó para él un instrumento muy adecuado para llevar a cabo un doble proceso de autoafirmación, tanto personal en el interior, como nacional frente al exterior. Las distintas familias del Partido Nacional de la Revolución (PNR) mantenían una sorda discrepancia ideológica y todos los grupos de la oposición, salvo los aglutinados en torno a la Iglesia, se consideraban de una $u$ otra forma herederos de la Revolución. Cárdenas tuvo que soportar durante su mandato una fuerte oposición interna -provocada por las medidas socializadorasque se endureció principalmente a partir de 193862 .

Desde el comienzo de la guerra española, Cárdenas dejó claro el lado hacia el que se orientaban sus simpatías. Bajo su inspiración se inició un apoyo continuado a la República que ha pasado a formar parte de la autocomprensión de la mexicanidad 63 . Con todo, la opinión pública se dividió en el país. Los sectores conservadores tendieron a apoyar a los sublevados, en tanto que la izquierda y el movimiento obrero divisaron en los acontecimientos de España una repetición de su propia lucha.

También desde el punto de vista internacional se daban cita en la Administración Cárdenas elementos que apuntaban en el mismo sentido: se ligaban a una clara actitud de condena del fascismo y del imperialismo, que si lograba inspirar la política de las potencias podía contribuir a realzar la posición exterior del país. Las intervenciones americanas no se habían olvidado 64 . Por otra parte, en la diplomacia mexicana, la guerra civil española, provocó algunas fracturas. A las renuncias -destituciones- de los dos embajadores mexicanos en España, la ya mencionada

62 Vid. R. Alonso de la Calle, L. Sanz García y G. Vázquez Chamorao, "La España nacionalista y el México cardenista. Diplomacia, prensa e ideología (1936-1940)", en VV.AA.: La política exterior de España en el siglo XX. Congreso Internacional, dirigido por Javier Tusell (Madrid, 10, 11, 12, 13 de diciembre de 1997). Madrid, UNED, 1997, pp. 217-231.

63 Vid. A. VIÑAs, "Las dictaduras con Franco, la República sola", en VV.AA, La intervención extranjera I. Politica y diplomacia. Col. Biblioteca de la guerra civil. V.4., op. cit.; p. 17. Sobre la posición internacional de México ante la guerra civil española, véanse, entre otros, AHDM, México y España: solidaridad y asilo político. México, secretaría de Relaciones Exteriores, pp. 149-202; J. A. MATESANZ, "Las raices...", pp. 179-235; J. A. MATESANz (comp.), México y la República española. Antología de documentos, 1931-1977, México, Centro Republicano Español, 1978, pássim.

64 Vid. A. Viñas, op. cit; ;pp. 17-18.

65 Véanse. J. A. MATESANZ, "Las raices...", pp. 200-212; T.G. PowelL, op. cit.;p. 66. La carta 
de Manuel Pérez Treviño (1936), a la que se uniría la de Ramón P. De Negri, (1937), por sus discrepancias con Cárdenas en el asunto del asilo diplomático 65 , se sumó el hecho de que el secretario de Relaciones Exteriores, Eduardo Hay, mostró cierta indiferencia hacia la República, hasta el punto de provocar la desconfianza del presidente, quien, en los asuntos relativos a nuestro país, procuró tratar siempre con el subsecretario, Ramón Beteta 66.

En lo que respecta a Félix Gordón Ordás, desde mediados de julio de 1936, además de trabajar en la incertidumbre motivada por la escasez de información fidedigna que le sirviese para contrarrestar las noticias tendenciosas por parte de la prensa conservadora mexicana 67 , quedó al frente de una legación prácticamente vacía. El primer secretario de embajada y encargado de negocios, Ramón $M .^{a}$ de Pujadas, el segundo, Miguel Teus, y el tercero, Nuñez Iglesias, de vacaciones en España, se adhirieron a los sublevados. El canciller de la embajada, José M. Argüelles, que se mantuvo fiel a la República, se encontraba en España en una misión oficial y no regresaría hasta julio de 1937 68. También mantendrían su adhesión, el agregado comercial, José Lión Depetre, y el cónsul general en México, Emiliano Zapico, quienes colaboraron activamente en todas las tareas de la legación.

Los esfuerzos por recomponer el servicio exterior del Ministerio de Estado estuvieron profundamente ligados a la evolución del resto de los aparatos del Estado republicano. En Hispanoamérica aparecieron los primeros intentos de reorganización en el verano de1937.

Por esas fechas se incorporaría a la embajada española en México, José Loredo Aparicio, quien desempeñaría, junto con Argüelles, las funciones de encargado de negocios durante las ausencias de Gordón Ordás ${ }^{69}$. El embajador, tuvo que solucionar igualmente la desestructuración

de renuncia del embajador Ramón P. de Negri a L. Cárdenas, en AMAE. R. Leg. 996. Exp. 97.

66 Vid. T. G. POWELL, op. cit.; p. 63.

67 Los telegramas enviados por F. Gordón Ordás al M. de Estado, solicitando información en AMAE. R. Leg. 527. Exp. 15. Sobre su actividad para contrarrestar las informaciones de la prensa conservadora mexicana Vid. F. GORDÓN ORDÁs, “Mi política fuera...", pp. 345-348.

68 Marina Casanova ha elaborado una lista con las adhesiones y dimisiones de los diplomáticos españoles producidas an los primeros dias del conflicto, según constaba en los telegramas que enviaron al Ministerio de Estado. En esta lista aparece la fecha de su admisión, separación o jubilación en el Cuerpo diplomático franquista. En elia aparecen el nombre de estos cuatro diplomáticos. Vic. M. CASANOVA, op. cit.; pp. 251-258.

69 Vid. N. TABANERA, “Las relaciones...", pp. 460-461.

70 Entre ellas, la de Cuba, en donde Gordón Ordás con la ayuda de Salvador Etcheverria, 
de algunas de las representaciones republicanas más próximas 70 , y ante la falta de la misma en algunos países hispanoamericanos, consiguió que a lo largo de 1937 las representaciones diplomáticas de México en Ecuador, Panamá, Perú y Uruguay se hicieran cargo de la defensa de los intereses de la República española 71.

De estas desafecciones, la de más transcendencia fue la de Ramón M. ${ }^{\text {a }}$ de Pujadas. Éste, tras haber enviado al Ministerio de Estado un telegrama de adhesión a la República el día 25 de julio, dos días más tarde, Gordón recibía un cablegrama de Burgos, del presidente de la Junta de Defensa Nacional, Miguel Cabanellas, informándole que había sido destituido y que debía entregar la legación al secretario más antiguo. En respuesta a la negativa del embajador, Pujadas se presentó en el despacho del secretario de Exteriores, Eduardo Hay, mostrando los cablegramas recibidos de la zona rebelde, así como una nota que recogía su intención de establecer una nueva representación española en su domicilio privado. Eduardo Hay, previamente informado por Gordón de lo sucedido, anotó de su puño y letra en dicha nota: «Al archivo por no reconocerse ninguna personalidad al firmante». Pujadas se llevó consigo una parte del archivo de la embajada y continuó operando en México recibiendo y transmitiendo información a la Junta de Defensa Nacional. Sería expulsado del país el 23 de diciembre de 1936. Sin embargo, poco antes de su expulsión nombró como representante de la España franquista en ese país a Augusto Ibañez Serrano ${ }^{72}$. La expulsión de Pujadas, fue el primer revés de los franquistas en sus intentos de obtener el reconocimiento diplomático del gobierno mexicano. Además de estas desafecciones, el embajador comunicaba al Ministerio de Estado otra más: «(...) Aparte de estas muestras de cordial simpatía hacia el gobierno republicano [por parte de México] (...) he de señalar como contraste doloroso, que la inmensa mayoría de la Colonia española no

futuro cónsul de España en Veracruz, tuvo que desmontar la red de espionaje a favor de Falange, dirigida por el cónsul general en La Habana, Jaime Montero de Madrazo, quien oficialmente había dado su adhesión a la República. Vid. S. ETCheVarRía Brañas, Eclipse en España, A Coruña, Ed. Do Castro, 1989, pp. 35-47.

71 Sobre la ayuda prestada por la legación mexicana en Quito, Vid. AMAE. R. Leg. 979. Exp. 1.

72 El informe de Gordón Ordás comunicando al M. ${ }^{2}$ de Estado la deserción de R. M..$^{\text {de }}$ Pujadas, en AMAE. R. Leg. 527. Exp. 11; la nota de R. M." de Pujadas a Eduardo Hay, en AHDM, “México y España...", pp. 151-152. Un relato detallado de este hecho en F. GoRdón ORDÁs, “Mi política fuera ...", pp. 423-426. Véanse, también: R. PÉREZ MONTFORT, op. cit.; p. 123; J. A. MATESANZ, “Las raices...», pp. 75-78.

73 Vid. F. Gordón Ordás a M.9 de Estado, 4 de agosto de 1936, AMAE. R. Leg 527. Exp. 11. 
ha recatado su simpatía por la rebelión militar, expresándola a veces en formas antisociales (...)" 73 .

Al tiempo que el embajador conseguia poner en orden la legación, acometió dos actividades que centrarían sus esfuerzos a lo largo de la contienda y que fueron la obtención de ayuda material y el apoyo político de los sectores mexicanos más comprometidos con la causa de la República.

En las fuentes consultadas en el Archivo del Ministerio de Asuntos Exteriores se constata la actividad frenética - discursos, conferencias, artículos de prensa, asistencia a exposiciones, congresos, actos de homenaje a la República Española...- desplegada por cada uno los miembros de la embajada, y de ésa como institución. En relación a esto último, la legación publicaba todos los dias un Boletín informativo y el semanario La Gaceta Española, a fin de dar a conocer la evolución de la contienda. Los diversos actos estaban casi siempre organizados por el sindicato obrero C.T.M. y su líder, el intelectual Vicente Lombardo Toledano, con el apoyo de grupos mexicanos y españoles. Entre los primeros destacó la Sociedad Amigos de España, y entre los segundos, el Frente Popular Español 74.

Pero como se dijo, el México cardenista no era ideológicamente homogéneo y los que se oponían al presidente y a su programa de gobierno optaron por iorpedear el despliegue propagandístico anterior. Todo ello, en un país, que a juicio de algunos autores, exhibía su antifascismo como seña de identidad de un régimen político cada vez menos revolucionario, y en el que, al igual que sucedía en las repúblicas vecinas, las directrices diplomáticas norteamericanas derivadas de la «Buena Vecindad», resultaban decisivas 75 .

Este complejo entramado de fuerzas colocó a Cárdenas en un difícil equilibrio en el que el pragmatismo político y simpatías personales, que le llevaba a dar su apoyo incondicional a la República, no le impedía, aunque en bastante menor medida, una tolerancia ideológica hacia los ene-

Un estudio de la reacción de la colonia española en México ante la guerra civil en, C. PANDO, "La colonia...”, pp. 349-359.

74 F. Gordón Ordás a M. de Estado, 12 de julio de 1938, AMAE. R. Leg. 979. Exp. 2. (Apéndice documental. núm. 21). Este informe constituye una síntesis de la propaganda desarroliada por la embajada a nivel institucional, asi como por cada uno de sus miembros.

75 Vid. R. PARDo, ;Con Franco hacia el Imperio! La política exterior española en América Latina 1939-1945. Tesis Dcctoral. Madrid, UNED, 1995, pp. 49-82

76 Sobre la deserción de cadetes, Vid. J. M.9 Argüelles a M.9 de Estado, 10 de agosto de 
migos de ésta, que por otra parte, también eran los suyos. Pero entre éstos se hallaban sectores influyentes de la sociedad mexicana de cuyo apoyo el presidente no podía prescindir.

Los resultados de esta situación no se hicieron esperar. Desde mediados de 1937, la embajada, pero con especial ensañamiento, el embajador, fueron objeto de una agresiva campaña de difamaciones por parte de la prensa conservadora y filo-fascista, tanto nacional como española: Excélsior, El Universal, la Prensa, Omega, Todo, El Diario Español.... Los asuntos en los que se vio envuelta la legación fueron diversos: Desde la deserción de unos cadetes del Colegio Militar de San Jacinto, la revuelta de Cedillo contra Cárdenas en San Luis de Potosi, el reclutamiento de voluntarios, hasta los orígenes familiares de Félix Gordón Ordás ${ }^{76 .}$

Estas campañas de prensa iban acompañadas de la actuación de los grupos fascistas mexicanos, como los Camisas Doradas, la Confederación de Clase Media o la Unión Nacional Sinarquista, y desde el verano de 1937 de las actividades de lo que en poco tiempo sería la Falange Española Tradicionalista y de las Juventudes de Ofensiva Nacional Sindicalista (FET y de las JONS) 77.

La embajada española no hizo nunca ninguna protesta oficial, pero en los informes de nuestros diplomáticos a Barcelona, se comprueba que su desconcierto y su preocupación eran constantes. En agosto de 1938, José Loredo Aparicio, exponía la situación al titular de Estado, Julio Álvarez del Vayo: "(...) Queda, sin embargo, un punto oscuro en este problema que apasiona a la sociedad mexicana, y es la actitud del Sr. Presidente general Lázaro Cárdenas ante las cuestiones de las libertades de prensa, reunión, manifestación etc. Las continuas declaraciones del Sr. Presidente favorables a estos derechos políticos entendidos de un modo absoluto e ilimitado; sus actos de benevolencia excesiva contra los infractores, la excesiva tolerancia ante las campañas que dolosamente combaten la política que proclama en sus actos y discursos, son las causas indudables de esa acometividad de la prensa de derechas y de la

1937, AMAE. R. Leg. 996. Exp. 105; sobre reclutamiento de voluntarios, Vid. J. Loredo Aparicio a M. ${ }^{9}$ de Estado, 13 de noviembre de 1937, AMAE: R: Leg. 979. Exp. 2; sobre la revuelta de CediIlo, Vid. F. Gordón Ordás a M. de Estado, 11 de julio de 1938, AMAE. R. Leg. 996. Exp. 55. Una valoración personal de estos acontecimientos por parte del embajador, en F. GORDÓN ORDÁs, «Mi política fuera...", pp. 439-469.

77 Sobre la actuación de la prensa y de los grupos fascistas mexicanos y españoles en México, Vid. R. Pérez MONTFORT, op. cit.; pp. 123-143.

78 J. Loredo Aparicio a J. Álvarez del Vayo, 6 de agosto de 1938, AMAE. R. Leg. 996. Exp. 54. 
audacia e incremento del fascismo. Pudiera ser que el Sr Presidente quisiera tener la mano abierta hasta el momento en que creyera decidirse a obrar con energía (...) pero los efectos por el momento son: la impunidad y auge del fascismo en México; el que los elementos revolucionarios se sienten inquietos, postergados, desamparados (...). En suma, que llegará un momento -peligroso si se tiene en cuenta que se aproxima la nueva campaña presidencial- en que el general Cárdenas se quedará sin el apoyo de una opinión pública, que es necesaria para gobernar con eficacia» 78 .

El diplomático no se equivocó en sus predicciones, al final de la guerra española Cárdenas expulsó a varios miembros de Falange y obstaculizó seriamente sus actividades. Y, según afirma E. Krauze: «Negar que Cárdenas terminó su periodo presidencial en medio de una notoria, que no generalizada, impopularidad, sería querer tapar el sol con un dedo" 79 . A mediados de 1938, la situación de F. Gordón Ordás era también muy complicada. El embajador intentaba con poco éxitc llevar adelante una actuación diplomática que satisficiera al mismo tiempo a los gobiernos de Barcelona, México y EE.UU. Su continuidad al frente de la embajada, era cuestionada. En este sentido, su difícil relación con el Ministerio de Estado se puso especialmente de manifiesto al ser relegado de las diversas gestiones diplomáticas entre México y España en el tema de los refugiados ${ }^{80}$. Según se deduce de la documentación manejada y de sus memorias, la embajada española en México, y en concreto, él como embajador, desconocian, a la altura de abril de 1938, en qué estado se encontraban las negociaciones sobre este tema. En uno de sus viajes a Valencia en ju-

Según M. Quijada, el gobierno de L. Cárdenas obstaculizó las campañas destinadas a la obtención de ayudas materiales para el bando rebelde y ordenó prohibir la propaganda franquista en las radios privadas, cines y teatros. No así en la prerisa. Vid. M. QuiJADA, N. TABANERA y J. M. AZCONA; «Actitudes ante la guerra civil española en las sociedades receptoras», en VIVES. P., VEGA, P. y Oramburu, O. (coords.): Historia general de la emigración española a lberoamerica, Madrid, H. 16/ CEDEAL, 1992, pp. 478-479. Según Powell, esto se debió a que el aito grado de analfabetismo en la población mexicana circunscribía el alcance de la prensa escrita a sectores minoritarios. Vid. T.G. POWELL, op. cit;; p. 78.

79 E. Krauze, op. cit.; p. 169.

80 El tema de las gestiones diplomáticas para preparar la llegada masiva de refugiados puede consultarse entre otros en: V. ALONSO MALDONADO, "Vías políticas y diplomáticas del exilio", en VV.AA.: El exilio español en México, 1939-1982, México, FCE, 1978, pp. 25-53; L. CÁrdenAs, op. cit.; pp. 369 y 425; J. SimEÓN VIDARTE, Todos fuimos culpables, México, FCE, 1973, pp. 765-791; M. AZAÑA, Obras completas. Memorias politicas y de guerra, V. IV. México, Oasis, 1966-1968, pp. 695-697; L. de LleRA (dir.), El último exilio español en América, Madrid, Mapfre, 1996, pp. 67-74.

81 F. GoRdón ORDÁs, “Mi política fuera...", pp. 775.

82 lbídem, pp. 776-777. Acerca de su participación en la llegada de los 500 niños de More- 
nio de 1937, Gordón Ordás mantuvo una serie de conversaciones privadas con el Ministro de Estado, con el Presidente del Consejo de Ministros y de las Cortes: "(...) quienes compartieron mis preocupaciones sobre la grave situación en que quedarían muchísimos republicanos en el caso de que fuéramos derrotados por aquella guerra sin cuartel, pero todos ellos consideraron prematuro discurrir sobre tal contingencia y a mi entonces me lo pareció también» 81 .

En los meses posteriores, envió una serie de cablegramas al Ministerio de Estado, que no fueron contestados: «(...) pero hasta en este mismo silencio oficial creí encontrar como una aprobación tácita, aunque sin compartir la responsabilidad, a lo que yo pudiera iniciar en el momento que considerase oportuno sobre inmigraciones republicanas". Así las cosas, comenzó una ronda de conversaciones "en el más riguroso secreto" con Cárdenas y el secretario de Gobernación, García Téllez. Del resultado de las mismas informó al Ministerio de Estado, sin obtener respuesta 82.

El 16 de abril de 1938, Gordón informaba a Julio Álvarez del Vayo de las declaraciones de García Téllez aparecidas el día 10 en El Nacional, sobre la decisión del Gobierno mexicano de dar entrada a los refugiados españoles 83.

El día 24 de ese mismo mes, Julio Álvarez del Vayo, enviaba una circular a todas las representaciones diplomáticas republicanas sobre la actitud que debía observar su personal en orden a evitar cualquier comportamiento que pudiera ser interpretado como signo de derrotismo del Gobierno de la República y de su ejército: «(...) la posición del Agente diplomático español exige de él una conducta escrupulosa, atinada, discretísima (...). Lo que en otros momentos pudiera denominarse flaqueza de ánimo o excepticismo (sic), se llama hoy traición y como tal será considerado (...) Y faltará a ese deber quien acepte siquiera sea en el seno de la intimidad, la hipótesis de un definitivo aplastamiento del pueblo español (...); quien manifieste ante redacciones, agencias periodisticas o personalidades extranjeras su ansiedad por noticias o precisiones que sólo debe aguardar de las autoridades españolas y sus órganos (...)».

lia, Vid. AHDM, «México y España...» pp. 209-210.

83 F. Gordón Ordás a J. Álvarez del Vayo, 16 de abril de 1938, AMAE. R. Leg. 996. Exp. 98. El informe se limita a transcribir literalmente la noticia dada por El Nacional y el editorial comentán. dola.

84 Circular núm. 47 de $M^{9}$ de Estado, Barcelona, 24 de abril de 1938 y la respuesta de $F$. Gordón Ordás, 18 de mayo de 1938, en AGA. AE. 10. 54/54. 03.02. 
F. Gordón Ordás se sintió personalmente aludido, y el día 18 de mayo contestaba al ministro: «(...) en la seguridad de que ni V.E. ni el gobierno han podido pensar ni un momento que puedan afectar a esta representación ninguno de los conceptos genéricos de crítica para los agentes diplomáticos que en ella se exponen. (...) Confío en que V.E. no considere prueba de flaqueza de ánimo en mí, si no indicio de previsión para un posible futuro desgraciado, el contenido de mi telegrama (...) Las conversaciones a que en el aludo se han llevado hasta ahora en la más absoluta reserva con el Sr. Presidente de la República de los Estados Unidos Mexicanos y con varias autoridades competentes y opino que es de gran conveniencia tener previsto hasta en sus menores detalles un plan de salvación de numerosas familias españolas (...)” 84 .

Unos dias más tarde, el Consejo de Ministros, nombraba a Indalecio Prieto nuevo embajador de España en México. Prieto decidió no aceptar el cargo hasta comentarlo con Manuel Azaña, quien se enteraría de la noticia el 9 de mayo, negándose a dar su conformidad por considerar el hecho una maniobra política de Negrín contra él: «(...) Como el presidente sabe que mis puntos de vista son casi iguales a los de Prieto, privarme de una solución política posible, aislarme, quedarse solo, como único presidente posible, encerrarme (...) grosería, descortesía, olvido y menosprecio de mi función tramitando el asunto sin mi anuencia y sin mi conocimiento: lo saben el Gobierno, los partidos, el interesado y el Gobierno mexicano, la legación en Londres, el público barcelonés y yo no» 85.

F. Gordón Ordás recibió un telegrama el 28 de abril, en el que se le comunicaba que se había solicitado el placet para su nombramiento como embajador en La Habana, sin añadir nada acerca de su continuidad en México, enterándose de la solicitud del placet para Prieto por los periódicos mexicanos 86 . A medida que pasaba el tiempo, y dado que no recibía ninguna comunicación oficial acerca de su continuidad en la embajada de México: “(...) pero como estos raros silencios eran muy frecuentes consideré que en el de este caso quedaba implícitamente confirmada mi suposición y, en efecto, estuve simultaneando las dos embajadas, hasta el final de la guerra» 87.

85 M. AZAÑA, Obras completas. Memorias políticas y de guerra. México, Oasis, 1966-1968; vol. IV [Reedición, Madrid, Giner, 1990], pp. 880-881.

86 Vid. F. GOADÓN ORDÁs, «Mi política fuera...», pp. 788-789.

87 Ibidem

88 Vid. R. PARDo, «Hispanoamérica en la política nacionalista, 1936-39", Espacio, Tiempo y Forma, Serie V. Núm. 5 (1992), p. 215. 
Por su parte, para los franquistas, en el continente americano, donde las cuestiones conectadas a la actividad militar tuvieron menos relevancia, la consecución del reconocimiento diplomático - de facto o de iurese convirtió en prioridad fundamental para neutralizar la acción republicana. Era preciso conseguir ciertas prerrogativas jurídicas a fin de emitir pasaportes, ejercer las funciones consulares, defender el uso de la bandera bicolor, organizar actos de propaganda nacionalista o mantener contactos con las autoridades locales. Resultaba fundamental para el funcionamiento normal de las actividades bilaterales: del comercio y de la protección de los intereses españoles. Sin el requisito del reconocimiento, sólo las autoridades republicanas podian disfrutar de tales atribuciones como agentes diplomáticos de un estado soberano 88 .

En junio de 1938, en un clima de euforia: «Por los continuos triunfos de nuestras armas, el incesante progreso material del país, la paz moral de nuestra España unida en torno al Caudillo (...)", el Ministerio de Asuntos Exteriores enviaba a su representante en La Paz unas instrucciones para el ejercicio de la representación oficiosa. En ellas se aconsejaban dos niveles de actuación en la política del Nuevo Estado en América. Por una parte, el diplomático y propagandístico en busca del reconocimiento jurídico. Por otra, la acción sobre las colonias españolas: trabajando por su protección, unión y comunicación con la España Nacional. Para ello: «(...) En los métodos de gestión será preferible elegir para evitar relaciones hostiles y perjudiciales (...), no ya las polémicas de prensa, sino el conducto más eficaz y discreto de sus conexiones privadas con los círculos oficiales y con las personalidades del pais de ideas simpatizantes con el Movimiento. Conviene por ello, que sin abandonar la propaganda patriótica (...) adopte una actitud constructiva, evitando violencias innecesarias, con reflejos perjudiciales para nuestra situación de estado no reconocido (...)". Al lado de esto, era imprescindible, no ya el respeto, sino incluso la disciplina a las autoridades del pais en cuestión 89 .

El sucesor de Ramón M..$^{2}$ de Pujadas como representante oficioso de Franco fue Augusto Ibáñez Serrano. Español, naturalizado mexicano - lo que evitaba la aplicación del artículo 33 de la constitución mexicana sobre expulsión de extranjeros-, y Jefe de Falange Española en ese país desde que ésta comenzara a funcionar en septiembre de 1937. Pujadas

89 Vid. Instrucciones del Ministerio de Asuntos Exteriores para el ejercicio de la representación, dirigidas al representante del Estado en La Paz. Burgos, 18 de junio de 1938. AMAE. R. Leg. 1003. Exp. 1; Vid. también, R. PARDo, “Con Franco...", pp. 57-58.

90 AMAE. R. Leg. 996. Exp. 20; Leg. 979. Exp. 1 y AMAE. RE. C. 54. (Sección diplomática especial) 
antes de ser expulsado de la legación española y posteriormente del país, entregó el archivo de la embajada a lbáñez, por lo que éste se convirtió extraoficialmente en el portador de la mayor parte de la información sobre la colonia española en México. Además, Ibáñez mantenía contactos con la Secretaria de Relaciones Exteriores y en concreto, según informes de la embajada española que seguía de cerca sus actividades, con Eduardo Hay 90.

La diplomacia franquista concibió esperanzas de mejorar las relaciones con México en la primavera de 1938 y en enero de 1939 ante las dificultades mexicanas con las potencias anglosajonas por la nacionalización petrolera. En abril de 1938, Ibañez proponía a J. F. de Cárdenas ir tanteando el terreno para el futuro reconocimiento diplomáti$c o$. Según aquél, en las esferas oficiales mexicanas y "a pesar de lo que se diga", se veía la conveniencia inmediata de establecer relaciones con Franco, aunque, añadía, que los rumores partían de "elementos oficiales que lo hacen exclusivamente exponiendo el punto de vista de ellos mismos" 91 .

J. F. de Cárdenas reenvió el informe de Ibáñez a Ramón M. de Pujadas, Jefe de Política de América y Asia en el recién creado Ministerio de Asuntos Exteriores, el cual, expuso su opinión al ministro Gómez-Jordana en un informe de 17 de mayo de 1938. Según Pujadas, buen conocedor de la situación y poco dado a excesos optimistas, en México "no existe el llamado ambiente oficial y si existe nos es francamente adverso". Según él, no había ningún indicio de un cambio de orientación y sería improcedente dar un paso en el acercamiento, que en cualquier caso debería venir, en primer lugar, de México. En este sentido, sus esperanzas eran más bien nulas ya que a su juicio: «(...) México será, con excepción de Rusia, el último país que reconocerá el triunfo de nuestras armas y la existencia de un gobierno genuinamente español»92.

A pesar de las recomendaciones de Pujadas, en el verano de ese mismo año, un grupo reducido de falangistas españoles viajó a Veracruz para recibir a dos representarites del régimen que venían de España con la comisión de preparar el ambiente para el anhelado reconocimiento. Se tra-

91 A. Ibáñez Serrano a J. F. de Cárdenas, 1 de abril, 1938. AMAE. R. Leg. 1005. Exp.5.

92 J. F. de Cárdenas a R. M." de Pujadas, Nueva York, 7 de abril, 1938, Informe de Pujadas a Jordana, Burgos, 17 de mayo, 1938. AMAE. Leg. 1005.Exp. 5. Vid. R. Pardo "Con Franco...", p.105.

93 Sobre los comités de ayuda a Franco, Véanse. AMAE. R. Leg. 1003. Exp. 1; R. Pérez MONTFORT, op. cit.; pp. 143-144, R. PARDO, "Con Franco...", p. 58. 
taba del conde Juan José Ruano y del jesuita Julio Vértiz. Coincidiendo con su llegada se intensificaron las labores de propaganda con el apoyo de la prensa y de grupos tanto mexicanos como españoles: recaudación de fondos, celebración del Plato Único, pequeños mítines... 93.

Pero por las mismas fechas el gobierno de Cárdenas tomaba medidas contra dichas actividades. Ibáñez replegó su actividad, pero no así otros miembros de la organización cuyas actividades vandálicas y provocadoras eran objeto de constantes reproches entre los representantes diplomáticos franquistas en América y la cúpula de aquella en España. Todo ello en conexión con el convuiso proceso de unificación de FET-JONS, en abril de 193794 .

En este clima tan desfavorable, a finales de enero de 1939 surgió otro intento para conseguir el contacto diplomático. Esta vez la iniciativa partió del escritor Pedro González Blanco, quien desde Lisboa envió al ministro de Educación Nacional, Pedro Sainz Rodríguez, un memorándum en el que exponía las causas de orden económico, político y «espiritual», que a su juicio existían para iniciar un acercamiento, "preludio" de las relaciones diplomáticas «normales». Sainz Rodríguez dio traslado de todo ello a Jordana, aconsejando que a Pedro González: «(...) se le puede emplear para todo dándole dinero u ocasión de ganarlo (...) podria ser utilísimo ejerciendo una especie de alto espionaje». Jordana, de nuevo, acudió a Pujadas, quién le contestó el 14 de febrero de 1939, con un informe en el que repetía casi textualmente lo dicho en el de mayo de 1938, pero añadía, en un tono que dejaba entrever cierta rabia y frustración, que al final México estaría obligado al reconocimiento: «(...) y que en aquel momento nos interesa no tener que agradecer ninguna actitud de tardía benevolencia, por lo demás improbable, que al suavizar asperezas y tratar de borrar agravios quitara fuerza para la resolución de los asuntos en aquél país (...)»95.

En abril de 1939, el final de la contienda española coincidió, por un lado, con la agitación que vivía México ante una nueva campaña electoral, y por otra, con la que vivía la comunidad internacional ante el inminente estallido de otra guerra mundial.

94 Véanse. A. Ibáñez Serrano a R. M." de Pujadas, 27 de agosto, 1938, AMAE. Leg. 1003. Exp. 1, AGA. AE. 26. 01/ C. 8727; R. PARDO, "Con Franco...", pp. 69-74.

95 La carta y el memorándum de Pedro González Blanco a Pedro Sainz Rodríguez, así como la carta de éste a Jordana y el informe de Pujadas en AMAE. R. Leg. 1005. Exp. 5.

96 Sobre este punto pueden consultarse entre otros: F. CAUDET, Hipótesis sobre el exilio republicano de 1939, Madrid, Fundación Universitaria española, 1997, pp. 207-243, S. CABEZA SÁN- 
A la incertidumbre y diversidad de opiniones de los franquistas acerca del reconocimiento mexicano, se puede apreciar en la documentación manejada, igualmente, la de los representantes diplomáticos republicanos sobre la inmediata postura oficial mexicana hacia ellos a pesar del apoyo que estaban recibiendo por parte de ese gobierno. Eran varias las razones para esa inquietud. La primera de ellas tenía su origen en los avatares por los que estaba pasando la legalidad constitucional del gobierno republicano ${ }^{96}$.

Tras la dimisión de Manuel Azaña como presidente de la República, el día 28 de febrero, Gordón Ordás envió su dimisión y rendición de cuentas como embajador en México y en la Habana al Ministerio de Estado, el día 31 de marzo ${ }^{97}$. En conversaciones que mantuvo con el presidente Cárdenas, el embajador obtuvo de él la firme declaración de que durante su mandato no se reconocería al gobierno de Franco. «Pero cuando pretendía sacarle a esa gallarda confesión la consecuencia natural de que se nos permitiese seguir con la embajada y el consulado abiertos, surgió la tan temida como esperada pregunta, que yo no podía honestamente contestar con un simple y rotundo "Si": ¿Continúa existiendo realmente un Gobierno republicano de España?» 98 .

Por otra parte, en septiembre de 1939, desde París, Julio Jaúregui (PNV), miembro de la Junta directiva del SERE, enviaba una nota al presidente del Gobierno de Euzkadi, J. M." Aguirre, comunicándole que en una reunión de dicho organismo celebrada el día 22 del mismo mes, su director, el Sr. Ossorio, les dio cuenta de la conversación que habian sostenido en esa ciudad el Ministro de México, Narciso Bassols, Negrín y Méndez Aspe.

En dicha reunión, el embajador mexicano les había manifestado la intención de su gobierno de poner fin a la emigración masiva de refugiados, debido a que la situación de guerra en Europa habia modificado sustancialmente la política anterior de su país hacia los refugiados políticos españoles. A juicio de Jaúregui, esta decisión se debía a las repercusiones que el enfrentamiento entre el SERE y la JARE, con el «Vita» por medio, causaba en la proyección de la imagen de los republicanos españoles, y

\footnotetext{
CHEz-Albornoz, Historia política de la Segunda Fepública en el exilio, Madrid, Fundación Universitaria Española, 1997, pp. 19-44, J. M." DEL VALL, las instituciones de la república española en el exilio, París, Ruedo Ibérico, 1976, pp. 9-18.

97 Vid. AGA. AE. 10. 54/54, 03.02.

98 Vid. F. GónÓn ORdÁs, «Mi politica fuera....", p. 259.

99 AMAE. R. Leg. 1787. Leg. 21.

100 Vid. F. Gordón ORDÁs, «Mi política fuera...», T.II. p. 260.
} 
a «una segunda razón más de fondo», como era que el gobierno mexicano venía reconsiderando su posición ante el gobierno de Franco, «dado que la situación de guerra en Europa afectaba considerablemente a la economía mexicana en cuanto a la posibilidad de impulsar sus exportaciones de petróleo y plata» 99.

En medio de estas especulaciones e incertidumbres, el día 17 de abril de 1939 se llevó a cabo la entrega de la embajada de España (edificio, archivo, muebles, automóvil e inventario) a la embajada de Cuba, que se haría cargo de los asuntos consulares de la República española. La ceremonia se llevó a cabo en los salones de la primera, mediante la firma del Acta correspondiente, por José Loredo Aparicio y Juan Manuel Carbonell. Según el ex-embajador: «(...) Al quedar libre aquel día histórico de funciones y responsabilidades sentí un extraño vacío dentro del alma, pero ni siquiera durante un minuto me invadió el desaliento (...)» 100.

En España, el 25 de abril, el ministro de Exteriores, Jordana enviaba un telegrama al gobernador militar de Madrid, ordenándole, que habiéndose enterado que en el edificio de la antigua embajada de México, «cerca del Gobierno rojo", continuaba la placa de "Embajada de Méjico" y asta de bandera, : «procede sin pérdida momento invite ocupantes edificio a retirar signo externo relacionada tal representación, hoy inexistente, haciéndolo efectuar por fuerzas sus órdenes caso de morosidad en cumplimiento esta orden»" 101.

México alegó para no reconocer al gobierno de Franco la Doctrina Estrada, especie de «cajón de sastre» y galimatías jurídico, que desde 1930 ha servido a México y al resto de los países de la comunidad internacional, incluida la España franquista, para ocultar tras sus intencionadamente ambiguos y contradictorios términos, lo que de acuerdo con su enunciado continua siendo una decisión discrecional, esto es, el reconocimiento diplomático de unos estados por otros.

El fundamento de la Doctrina Estrada estriba en suprimir el reconocimiento expreso de gobiernos extranjeros por considerar que el mismo es una práctica denigrante que implica inmiscuirse en los asuntos internos de otros Estados, con lo que conforma su práctica del reconocimiento a la política de no intervención de la que México se autoproclamaba en esa época un ardiente defensor. De acuerdo con esta doctrina, el no aceptar

101 AMAE. R. Leg. 1005. Exp. 5. El embajador mexicano Adalberto Tejada, cerró la embajada, llevándose el archivo, en marzo de 1935.

102 Acerca de la Doctrina Estrada aplicada al caso de España, Véanse, entre otros, L. LEVETY HOLLINSGWOR, op cit.; pp.137-140., L. ELWYNN SMITH, op. cit.; pp. 204-206., J. RUBIO, “Los re- 
la continuación de la embajada de la República española en México supuso por parte del Gobierno de este país una ruptura unilateral de relaciones con el Gobierno republicano español y por tanto, a juicio de algún sector historiográfico, dicha actitud mexicana denigró a ese Gobierno, especialmente cuando lo reconoció seis años después 102.

La historiografía reciente alega razones más concretas y convincentes para explicar la posición mexicana que tienen en cuenta el interés mismo del régimen mexicano en el proceso español, incluida la guerra civil, así como un contexto internacional en el que la política de Buena Vecindad de los EE.UU le permitió cierta autonomía de decisiones -la nacionalización petrolera--, pero que dada su dependencia económica respecto a su vecino, tuvo que compensarlas dándole satisfacción en otras, por ejemplo, apoyando su política de neutralidad hacia el conflicto español, no reconociendo por esa razón a ninguno de los dos gobiernos surgidos en España al finalizar nuestra contienda, en un momento en que el Departamento de Estado norteamericano se debatía entre aquellos que consideraban que las dificultades para la política exterior del país se debían a la expansión de la influencia comunista, y por el contrario aquellos que temían más el desarrollo del fascismo en Hispanoamérica 103.

\section{FUENTES DOCUMENTALES}

- Archivo de la Fundación Pablo Iglesias (Madrid). Correspondencia de la Embajada de España en México.

- Archivo General de la Administración (Alcalá de Henares). Fondo de Asuntos Exteriores: Embajada de España en México, Embajada de España en Washington.

- Archivo del Ministerio de Asuntos Exteriores (Madrid). Secciones: Archivo Renovado, Archivo de Barcelona, Archivo de Burgos y Archivo de Personal.

- Archivo General de la Guerra Civil Española (Salamanca). Sección Político Social: (inventarios de Madrid y Santander). Archivo Histórico-oral (exilio mexicano).

- Hemeroteca Nacional (Madrid).

- Hemeroteca Municipal (Madrid).

conocimientos diplomáticos del gobierno de la República en el exilio", Revista de política Internacional, Núm. 159 (1987), pp. 77-87.

103 Véanse, entre otros: R. PARDo, "Con Franco..." pp. 49-54; J. A. MATESANZ, “Las raices...», pp. 455-466, C. PANDO, “La colonia...», pp. 150-156. 